\title{
Marrow: 1-9
}

\section{Melissa Jacques}

En neuf vignettes, la relation entre le domestique et le public est représentée par une violence très souvent confondue avec l'amour. Ce sont des contes de l'enfance qui se trouvent mis en scène dans un paysage figé. La violence familiale et le racisme sont vus, comme à travers les yeux de l'enfant, dans une série de projections sur le monde de la nature. Le sang est versé; les corps d'animaux et d'humains sont mutilés et abandonnés dans l'indifférence. Il n'y a pourtant pas de réelles victimes. Ce qui est en jeu, c'est la survie, la résistance créatrice de l'enfant-fille et du psychique ainsi que la valeur littéraire d'une certaine indétermination. 


\section{Tang}

Something as simple as a glass of juice could bring the room to a standstill. My route, marked out in measured steps, extends before me in a knuckle-white grasp. Mid-stride, the wool of my green Christmas jumper scratches a ring around my neck. My arm aches. I hold it out, straight, as I've been told. While the juice runs rivulets: a tv tiger lily unfolding in the accelerated frames of time lapse over my fingers, in and between my hand and the glass.

In and between my hand. And the glass, illumined by the dust-mote glare of the winter sun. I look toward my sisters. A huddle of three. Hushed, we stand stock-still. Immobilized before the smack, the hand to break, the end to this unprecedented momentum. 


\section{Foul}

I know it's wrong so I lie and say only a couple of boyfriends. My dad nods and smiles.

My mom comes into my room when I'm asleep. The light hurts. She's yelling.

Look what he's done to me! And blood's coming out. A big long cut. Why did you tell him? You stupid little cunt, it's all your fault.

He has to leave. He gets work with a mining company, and moves north. When he comes home to visit I pee my bed because I don't want to have to get up and see him. In the summer she visits him and comes back with presents. A plastic deer on a round piece of shiny wood complete with plastic fawn. And a brooch. It's soft white leather and beads. It's two little boots hanging down.

Lynn Lake, Manitoba.

We're moving. 


\section{Borealis}

The flight was held over in La Pas. Mechanical difficulties. We waited in the airport for six hours. It was so cold we couldn't go outside. My sisters and I ran around the cramped terminal. We had roast-beef sandwiches wrapped in plastic. Someone gave my mom a six-pack of Coke.

When we arrived it was past midnight. With the windchill, the temperature was sixty degrees below zero. My father had given up waiting so we were driven home in a taxi. He met us outside. The light from the open doorway blazed around him. With shoulder-length hair and a full beard, his arms were held wide open.

Home was an apartment in a newly constructed company building. There were no curtains. $\mathrm{He}^{\prime} \mathrm{d}$ arranged for mattresses and blankets from one of the bunkhouses. We slept with them on the floor. The blankets were itchy. They smelled of sweat and vomit. I could hear my parents whispering in the other bedroom. I could hear my mother sobbing, softly, in the dark. Then I knew: we'd moved here forever. 


\section{Conjurer}

There wasn't much to see. Snow. The buildings across the street were hidden by a huge barricade of it. And ravens. Like Hitchcock's The Birds, they were everywhere.

Whenever I remember that picture window I think of a story. It's not a story of anyone I know. I can't even remember who told it, or to whom. I overheard it.

It's a story about an Indian. That's how it was framed. "There was this old Indian man and he died." The tacit understanding, on the part of both teller and audience, was that the man was drunk. He was discovered, identified, and transported back to his family for burial.

The crux of the story is as follows. The man was frozen solid. The plane that was to transport him was small, a Twin Otter. In order to get him onto the plane, they sawed him in half at the waist. I say this is the crux of the story but, in the version I heard, it was the punchline. 


\section{Arbor}

Those same long bracelets of skin and bone, finger to thumb, lift ankles high above my head. Breathy slither of belt to skin, cheeky welts, I'll give

you something. A whoosh and snap, thighs smarting, give. Give you something to cry.

We entered the bush two blocks from home. Right away he spotted a rabbit. A rabbit I didn't see. He pointed it out. It must have been very still because I couldn't see it. He loaded the bullet-a lead ball wrapped in a patch of clean white cotton-into the barrel, pushing it down with a brass-tipped ramrod.

An explosion. And the rabbit, I could see it now, had flipped forward onto its face with its tail stuck straight up.

It was still. Its shape suggested, because of the unusual angle of the tail, the shape of a duck.

We walked over. He picked it up by its hind legs. It was a golden brown, smooth, with a white stomach and tail.

Your mother won't cook these. What a waste.

Throwing it down he started away, further into the bush. 


\section{Indenture}

He was excited. A hoarder, he would gloat over acquisitions with glee. This one was better though. He wouldn't tell me what, he just said I had to see. I followed him to the freezer; I watched his shoulders tense as he lifted the heavy lid. A smile spread across his face as he looked down. I followed his gaze prepared, but not for this. He'd lined them up in neatly ordered piles. Multiple sets of wolves' jaws-teeth, bone and pieces of flesh-intact and frozen solid. 


\section{Oopik}

ptar-mi-gan \'tär-mi-gen \noun plural -gan or -gans

[modification of Scottish Gaelic tarmachan] (1599)

: any of various grouses (genus Lagopus) of northern regions with completely feathered feet. MERRIAM-WEBSTER'S DELUXE DICTIONARY

It was made of sealskin. Sleek and smooth, its lines were drawn in a simple curve down its back from its beak through to its tail. I'd saved up the five dollars and bought it from a woman who was a friend of some friends of my parents. She was young and pregnant.

We waited for them to wake up. Four of us in pink flannel, undershirts, leotards, wool socks and slippers. This waiting seemed to take forever. They could get up at any time. Then again, they might just sleep till supper.

Locked inside the two-bedroom company suite, we played at the kitchen sink, thinking up ways to waste time. Like turning bread back into dough - rip off the crusts, add water, and serve.

She was crying. Then she was screaming, yelling out the names of my parents, begging them to help her. And banging. The slump and slide of her body down the length of the door. The sound of contact, a fist against her face. She wasn't screaming now, but whimpering. Not to my parents, but to us.

They were awake, groggy, hazy, but awake enough to deliver explicit instructions: Don't you dare touch that fucking door. We can't let her in or we'll never hear the end of it. They couldn't hear her. As if she had $\mathrm{x}$-ray vision, they wouldn't leave their room.

We sat in a line across the floor facing her, and waited. The light from the hallway flashed from beneath the door with their movements. We'd seen light like this before, but never from outside our tiny apartment. 


\section{Siegecraft}

My father makes himself skin bags, envelopes of leather scraped clean of pigment, folded and dry. Lays them out with loving hands, fingers bleach bone white. He finds their texture reassuring, resistance delicate and nominal.

The twins. Hemmed in on either side by a sister (one older, one younger), together they were the middle child. Their sign was Taurus, borne out by a fierce stubbornness that even their gun-toting daddy could not break.

Approaching puberty, however, their spirit became less certain. In love, each with her respective David Cassidy or Donny Osmond, they often wondered, what next?

The flesh disintegrates, broken down and consumed by the very body that produces it. Gone, the round angry faces framed, each, in a mane of black curls. The brown eyes bulging, the small breasts hard like buttons on a chest almost translucent enough to reveal bone.

Obsessed with mirrors, they were watching. Ever vigilant, they wasted away. 
9. Slick

It was a trick glass: imperceptibly altered five-and-dime crystal concealing crevices, holes through which the juice could seep, seep slowly enough to pass unnoticed until I'd crossed the floor of the tiny kitchenette.

That juice traces our still sticky-wet surprise at having made it. Do you remember? I swear I could've died. I could've, almost, just about, died. 